\title{
Studentification in Stellenbosch, South Africa
}

\begin{abstract}
Globally, studentification has emerged as a prominent urban process, fast becoming entrenched in geographical discourse. Since the early 1990s, in both developed and developing world countries, an expansion in student enrolment has outstripped the ability of higher education institutions to provide adequate accommodation. These trends have been noted in South Africa too. The extent and impact of studentification on the urban geography of those places in which it has taken root is still poorly understood in both South Africa and the global South at large. This paper investigates studentification as experienced in one of South Africa's secondary cities Stellenbosch. An overview of generic studentification impacts is provided and the development of this process tracked. Thereafter, the motivation for living in these developments and the impacts of this process comes into view. It is argued that the areas affected by studentification have fundamentally changed in their physical and social character. Interestingly, a range of findings in the academic record were not present in the Stellenbosch context. Finally, it is suggested that studentification in South Africa requires greater research attention in a range of other urban settings in which this process has emerged. This is particularly urgent as it would appear that studentification can radically and very rapidly transform the geography of the areas in which it takes hold.
\end{abstract}

Keywords: studentification, Stellenbosch, South Africa, urban morphology

\section{Introduction}

Globally, there has been a dramatic increase in students enrolled at higher education institutions (HEIs) (Council for Higher Education, 2016: 9). These institutions have not been able to respond at a similar tempo in providing student accommodation, which resulted in an undersupply of student accommodation (Smith, 2009; Donaldson, 2014; Donaldson et al., 2014). While studying at HEIs, students, especially those studying at institutions that are far from their parental homes, are in need of accommodation (Ackermann \& Visser, 2016). As HEIs cannot currently provide all students with on-campus accommodation, alternative accommodation in the private sector have appeared in various formats (Benn, 2010; Donaldson et al., 2014; Ackermann \& Visser, 2016). Initially, single residential housing units were converted into houses in multiple occupation (HMOs), often along the periphery and surrounding neighbourhoods of the HEIs, and more recently, purpose-built student accommodation was created (PBSA) (Benn, 2010; Donaldson et al., 2014). These changes in land-use have had profound implications for the locations in which such developments have occurred (Hubbard, 2008; 2009).

The establishment of private student accommodation in the surrounding neighbourhoods is a phenomenon called studentification (Benn, 2010; Hubbard, 2009). In Sage et al.'s (2012a, 2012 b) view, studentification is used to describe both the migration of university students into established residential neighbourhoods and the associated impacts this holds. These impacts include cultural, economic, physical and social transformations. Studentification is associated with changes in household structures, local age profiles, facilities and services, local cultures and lifestyles, and differences in social class positions (Sage et al., 2012a). Donaldson et al. (2014) argue that spatial dysfunctionality is often the result of 
studentification and that the students' subculture is catered for over time, resulting in the exclusion of permanent residents. Fear of and social protest against the development of student accommodation in local residents' suburbs have been recorded as consequences of planning policies either initiating these developments or not regulating them (Donaldson et al., 2014).

Echoing international trends, South Africa has experienced dramatic expansion of students at HEIs since the early 1990s (Council of Higher Education, 2016). Most of these institutions are unable to house all their students. Despite the prevalence of this challenge, very little scholarship has focused on the impacts of the studentification process on both small and large urban areas (rare exceptions are Ackermann \& Visser, 2016; Benn, 2010; Donaldson et al., 2014). The aim of this investigation is to contribute towards addressing this paucity in scholarship through the empirical realities of Stellenbosch - arguably the urban context in which the process of studentification has had its most extensive impact in South Africa and indeed the African continent. The investigation unfolds in a number of sections of review and analysis. First, an overview of definitions and key issues in the current discourse is presented. Second, a general framing of the genesis of studentification in Stellenbosch and methodological issues are considered. Third, the investigation then sets out to establish the basic spatial expression of studentification in Stellenbosch. The central focus is on how studentification is spatially expressed in this setting. Fourth, an analysis of the students inhabiting this housing type and why they live there come into view. Finally, brief consideration is given to the various impacts studentification holds for those particular locales. In the concluding section, the main findings of the investigation are extrapolated to a broader canvas of studentification in urban South Africa and its implications considered. 


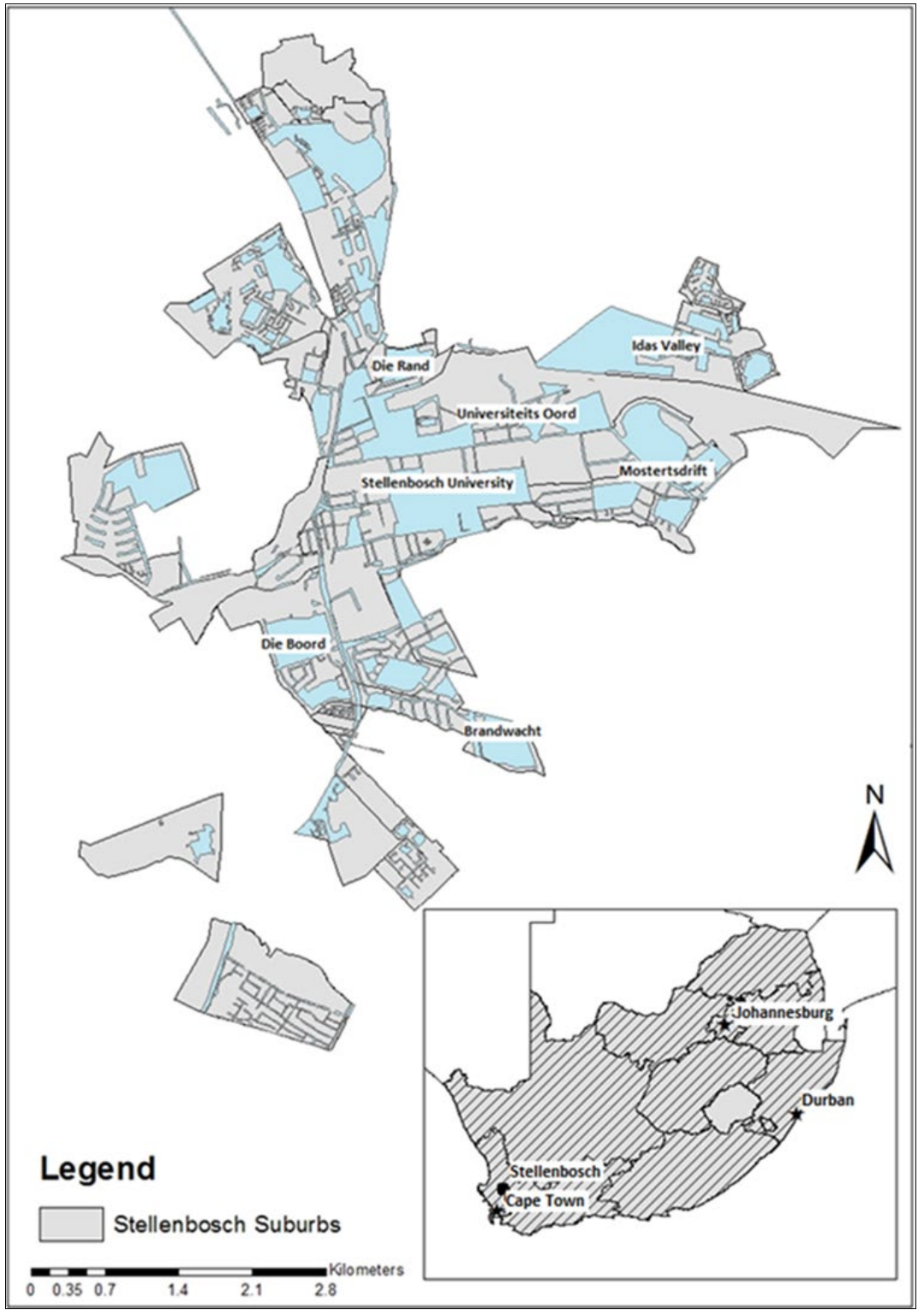

Figure 1: Location of Stellenbosch in South Africa (illustration: Gustav Visser and Dene Kisting).

\section{Current studentification discourses}

Sage et al. (2012a) argue that studentification became a phenomenon requiring academic reflection since the early 2000s. When students migrate to universities, they have two options: they can either live in accommodation provided by the university or in private sector housing (Garmendia et al., 2012; Smith \& Hubbard, 2014; Ackermann \& Visser, 2016). The increase in student enrolment at HEIs has made student accommodation provision unmanageable for most universities as they lacked adequate resources to satisfy the demand (Donaldson et al., 2014; Ackermann \& Visser, 2016). In the British context (the location of much of the geographical investigations), this has led to studentification (Rugg et al., 2002; Cochrane \& Williams, 2013). In most cases, studentification resulted in an influx of young, middle- and upper-class people into established, relatively inexpensive residential neighbourhoods, although the opposite has also been recorded. This process has sometimes been linked to gentrification (Smith, 2005; Sage et al., 2012a: 598; Boersma et al., 2013; 
Smith \& Hubbard, 2014). Either way, the concentration of students has been shown to have various geographical consequences (Macintyre, 2003; Steinacker, 2005).

Allison (2006: 80) mentions that cities contain concentrations of students, which leads to student enclaves. These enclaves or clusters of students create communities that are spatially and temporally linked to the academic calendar and campus lifestyle and that are usually in close proximity to the campus (Chatterton, 1999; Allison, 2006; Munro et al., 2009). These areas transform owing to the presence of student communities and this transformation is called studentification. There are two different private sector student accommodation types that affect residential neighbourhoods differently, namely home in multiple occupancy (HMOs) and purpose built student accommodation (PBSAs) (Ackermann \& Visser, 2016). The process of studentification does not only refer to the influx of students into residential neighbourhoods (Sage et al., 2012a; Smith \& Hubbard, 2014), but implies an activation of a range of social, cultural, economic and physical transformations (Fincher \& Shaw, 2011; Sage et al., 2012a; Donaldson et al., 2014; Ackermann \& Visser, 2016). Table 1 provides a summary of different studentification effects, categorised into four impact categories.

Table 1: Categorised effects of studentification.

\begin{tabular}{|c|c|c|c|}
\hline Social & Economic & Cultural & Physical \\
\hline $\begin{array}{l}\text { Demographic structure of } \\
\text { the local population }\end{array}$ & $\begin{array}{l}\text { Supply and demand for } \\
\text { housing }\end{array}$ & $\begin{array}{l}\text { Supply and demand for } \\
\text { specific leisure, } \\
\text { recreational and retail } \\
\text { facilities }\end{array}$ & $\begin{array}{l}\text { Levels of private vehicle } \\
\text { use and cycling and } \\
\text { walking }\end{array}$ \\
\hline $\begin{array}{l}\text { Level of population } \\
\text { density }\end{array}$ & $\begin{array}{l}\text { Buoyancy of housing } \\
\text { market }\end{array}$ & $\begin{array}{l}\text { Levels of antisocial } \\
\text { behaviour }\end{array}$ & $\begin{array}{l}\text { Levels of traffic } \\
\text { congestion }\end{array}$ \\
\hline $\begin{array}{l}\text { Levels of } \\
\text { stability/transience }\end{array}$ & $\begin{array}{l}\text { Portfolio of housing } \\
\text { market }\end{array}$ & $\begin{array}{l}\text { Levels of noise nuisance } \\
\text { from households, } \\
\text { pedestrians, taxis, private } \\
\text { vehicles }\end{array}$ & $\begin{array}{l}\text { Levels of visual } \\
\text { pollutions (to-let signs) }\end{array}$ \\
\hline $\begin{array}{l}\text { Turnover of } \\
\text { residents/property }\end{array}$ & $\begin{array}{l}\text { Flexibility of housing } \\
\text { stock }\end{array}$ & $\begin{array}{l}\text { (In)compatibility of } \\
\text { lifestyles }\end{array}$ & $\begin{array}{l}\text { Levels of litter and } \\
\text { rubbish }\end{array}$ \\
\hline $\begin{array}{l}\text { Cohesion of local } \\
\text { community and } \\
\text { community interactions }\end{array}$ & $\begin{array}{l}\text { Condition of housing } \\
\text { stock }\end{array}$ & $\begin{array}{l}\text { Supply of and demand for } \\
\text { levels of policing and } \\
\text { emergency services }\end{array}$ & $\begin{array}{l}\text { Upkeep of gardens and } \\
\text { driveways }\end{array}$ \\
\hline Levels of neighbourliness & $\begin{array}{l}\text { Spending levels within } \\
\text { local economy }\end{array}$ & & $\begin{array}{l}\text { Upkeep of external } \\
\text { environment }\end{array}$ \\
\hline $\begin{array}{l}\text { Meaning and symbolism } \\
\text { of location }\end{array}$ & $\begin{array}{l}\text { Levels of inward capital } \\
\text { investment }\end{array}$ & & $\begin{array}{l}\text { Levels of graffiti and } \\
\text { vandalism }\end{array}$ \\
\hline $\begin{array}{l}\text { Supply of and demand for } \\
\text { schools, GPs, dentists and } \\
\text { other health services }\end{array}$ & $\begin{array}{l}\text { Supply of and demand } \\
\text { for local retail, leisure } \\
\text { and recreational services }\end{array}$ & & \\
\hline $\begin{array}{l}\text { Supply of and demand for } \\
\text { public transport }\end{array}$ & $\begin{array}{l}\text { Seasonality of local } \\
\text { economy and services }\end{array}$ & & \\
\hline $\begin{array}{l}\text { Effectiveness of crime } \\
\text { prevention strategies and } \\
\text { self-policing }\end{array}$ & $\begin{array}{l}\text { Levels of housing } \\
\text { abandonment }\end{array}$ & & \\
\hline Trends of criminal activity & $\begin{array}{l}\text { Supply of and demand } \\
\text { for domestic services }\end{array}$ & & \\
\hline $\begin{array}{l}\text { Levels of electoral voting } \\
\text { and political affiliations }\end{array}$ & $\begin{array}{l}\text { Supply of and demand } \\
\text { for childcare services }\end{array}$ & & \\
\hline $\begin{array}{l}\text { Effectiveness of car } \\
\text { parking schemes and } \\
\text { provision }\end{array}$ & $\begin{array}{l}\text { Levels of council tax } \\
\text { revenue }\end{array}$ & & \\
\hline $\begin{array}{l}\text { Strength of local voluntary } \\
\text { schemes/sector }\end{array}$ & Local workforce & & \\
\hline
\end{tabular}


Levels of alcohol/drug

abuse

Health and well-being of

local population

Source: Smith and Holt (2007: 149).

As the need for student accommodation increases, so does the number of landlords and property developers who recognise the opportunity for renting out HMOs in specific areas, mostly those areas surrounding HEIs (Smith \& Hubbard, 2014). Subsequently, the increase in the demand for student accommodation eventually led to the development of PBSAs. Smith and Hubbard (2014) argues that the establishment of PBSAs is considered a coping mechanism for local authorities as PBSA development helped to control the growth of HMOs in residential neighbourhoods.

In the South African context, Ackermann and Visser (2016) and Donaldson et al. (2014) demonstrated that HMOs tend to have a greater impact on residential dynamics than PBSAs do. In HMOs, students tend to have gardens and refuse that is not well managed, accompanied by noise, vandalism and antisocial behaviour. The benefit of PBSAs, which makes them attractive to students, is that they are exclusive and students can still live offcampus but not in residential neighbourhoods. This separation between residential neighbourhoods and PBSA ensures that students (and their particular lifestyle and noise) are contained in a particular area (Sage et al., 2012a; Ackermann \& Visser, 2016). There is also the implication that there is a developmental path in studentification, setting out as a 'first wave' that marks the transition from family homes to HMOs, while the 'second wave' refers to the development of PBSAs (Sage et al., 2012a) and near deliberate student enclave development.

Students can impact the physical environment of the neighbourhoods and indirectly affect the way these neighbourhoods are controlled, planned and regulated (Donaldson et al., 2014). These impacts can be negative or positive e.g. students can contribute to both the environmental degradation of a neighbourhood and its wealth (Ackermann \& Visser, 2016). According to Ordor et al. (2010), the physical environment is upgraded when single-family homes are converted to HMOs, which in turn raises the property and rental prices. Benn (2010), however, is of the opinion that students can also contribute to physical and environmental decay such as weak electricity supply, vandalism, insufficient facilities, littering and overcrowding.

According to Smith and Hubbard (2014), university students unavoidably contribute to the trend of socio-spatial segregation. The social impact of studentification stems from the movement of students into residential neighbourhoods (Benn, 2010). Their entrance can disrupt a sense of cohesion, belonging and identity in a community as they tend to show a lack of interest when it comes to interacting with non-student residents, thereby contributing to the segregation (Benn, 2010; Ackermann \& Visser, 2016). Students moving into a neighbourhood affects population density (higher concentration of people) and diversity (greater variety of people) in an area (Donaldson et al., 2014; Ackermann \& Visser, 2016). When students live in university residences, they supposedly learn the rules and regulations of studenthood because they are naturally segregated into institutional spaces. They also form friendships and build relationships with fellow students. In private student accommodation, students become more independent and mature when they move into established residential neighbourhoods and participate in shared-home living where they are not obliged to follow 
any formalised institutional rules or regulations (Donaldson et al., 2014; Smith \& Hubbard, 2014).

Students' lifestyle, of which drunkenness and noise is often a part, is considered one of the most frequently mentioned negative impacts of studentification. As students continue to move into established residential neighbourhoods, many of the residents may become resentful when they realise that they are outnumbered by students (Smith \& Hubbard, 2014; Ackermann \& Visser, 2016). Thus, studentification influences the migration into and out of neighbourhoods, particularly the outward migration of established residents who are displaced, thereby affecting the demographics and related characteristics of the area. This results in the depopulation of non-student residents in neighbourhoods, causing these areas to become temporarily inhabited and resulting in 'ghost towns' during academic breaks (Sage et al., 2012a), which may ultimately lead to the closure of schools in the area due to an absence of families with young children (Sage et al., 2012a). It has also been observed that the inmigration of students is associated with an increase in crime within the neighbourhood (Munro et al., 2009). Crime rates tend to increase during university holidays, when the majority of students are not in the area, with the most common crime being cars that are broken into (Benn, 2010; Donaldson et al., 2014). The targets of crime tend to be students because they own expensive items but do not have security that would be deemed a sufficient form of protection (Munro et al., 2009). However, non-student residents are also affected by these crimes (Benn, 2010).

The transformation of local shops (take away restaurants, copyshops) and services (bars, nightclubs) and the contestation among residents and students, usually due to noise, littering and parking, are visible signs of studentification (Smith \& Hubbard, 2014). According to Donaldson et al. (2014) and Benn (2010), students change the lifestyle and consumer patterns of residents. Their presence, followed by visibly different cultures, consumer patterns and lifestyles, create unique product and service provisions (Ordor et al., 2010). With more students in the area, local businesses realise that students are their main clientele and that they should cater to their needs. This changes and diversifies the local culture where "traditional restaurants and bars are replaced by fast food restaurants and outlets" (Donaldson et al., 2014: 178). Students can be considered cultural investors as they might contribute to the diversity and urban revival of the neighbourhood and surrounding areas (Benn, 2010).

Taken as a whole, both the characteristics of the social groups and the area within which studentification manifests will determine whether its impacts are positive or negative (Ordor et al., 2010). There are various factors that contribute to students living in private accommodation such as property investors or letting agents, but other factors (including the distinct student lifestyle or culture) should also be considered (Donaldson et al., 2014). The possibility to convert, build or invest in HMOs and PBSAs depend not only on the demand for student housing, but also on the national legislation, i.e. policies, that regulate the development of student accommodation and whether the houses are suitable for conversion (Smith \& Hubbard, 2014). According to Smith and Hubbard (2014), there is a deficiency of knowledge and data regarding the scale of studentification.

\section{Stellenbosch in context and methodological notes}

Stellenbosch is home to a number of educational institutions such as Boland College, Isa Carstens Academy, Institute for Culinary Arts, Elizabeth Galloway Academy of Fashion 
Design and Stellenbosch Academy of Photography and Design, as well as Stellenbosch University (SU). The student population of these institutions have increased to such an extent that the provision of accommodation has become challenging for both these institutions and the private marketplace.

The largest HEI is SU. In 2016, SU enrolled a total of 30,854 students (Stellenbosch University, 2017a). This is 19,475 more than the 11,379 recorded in 1990 (which was the starting point of an era of higher education massification in South Africa) (Council for Higher Education, 2016). Over 26,000 of the enrolled students study on the main campus in Stellenbosch (it is a multi-campus university with specialist campuses in Cape Town, Saldanha, Wellington and Worcester). Of the 32 university residences, 26 are located in Stellenbosch, providing female, male, senior, co-ed and private, affiliated university accommodation. SU has the capacity to accommodate approximately 6,500 students within these residence formats, resulting in over 20,000 students seeking private accommodation. This makes it more difficult for students to find university accommodation placement. The university receives over 35,000 first-year applications but can only accommodate 5,000 new entrants annually. Of these, there are fewer than 2,000 places for newcomer students available in the SU student accommodation system (Stellenbosch University, 2017b). Therefore, receiving university-provided accommodation placement at SU is considered a "privilege and not a right". Applicants are generally required to have attained very high academic achievements, along with other accomplishments on cultural, leadership and sports levels.

Historically, HMOs in Stellenbosch were small relative to the total number of enrolled students. During the 1990s, HMOs became more popular (particularly for more senior students) and as university accommodation became increasingly scarce, academic achievement became a prerequisite for remaining in institutionally-provided accommodation. This presented an investment opportunity and resulted in private property investors acquiring former family homes (three to four bedrooms) to accommodate students who either wished to or had to leave university-provided accommodation. These properties were systematically expanded over time. A typical HMO in the 2010s could accommodate between 10 and 20 students. ${ }^{1}$

It was probably only a matter of time before larger property investment firms would see an opportunity in a more formalised approach to student housing provision. The entry of PBSAs, as opposed to family residences being converted and expanded (HMOs), as a property investment class came with the establishment of, among others, CampusKey in Stellenbosch (which now has a national footprint in a number of other cities in which HEIs are located) and Unilofts in Gauteng and the Free State. These investments have mainly been made at historically white Afrikaans universities (Free State, Johannesburg, North West, and Pretoria). The six PBSAs in Stellenbosch managed by CampusKey specifically vary dramatically in size (ranging between 55-250 bedrooms). Viewed at a national level, there are various providers that are even larger, some accommodating more than 400 students in different rooms, flats, studios and shared flat configurations.

Methodologically, this investigation draws primary on data collected over several months in 2017. A listing of all properties relevant to the study drew on 105 students' knowledge of

\footnotetext{
${ }^{1}$ As will be shown later, there is currently not much difference between HMOs and PBSAs in terms of facilities and services beyond the number of rooms available.
} 
existing HMOs and PBSAs they either lived in or knew of, informing the baseline location data-set (these where not on the whole the survey participants reported in the study - only a means by which to identity student housing). This was then augmented and vetted by five, well-established estate agents working in the central Stellenbosch student rental market. It also has to be noted that only neighbourhoods within walking distance of the university's main campus were included. Coordinates for the different student accommodation types were collected manually (using a GPS handheld device) and mapped. The student accommodation included HMOs and PBSA; however, it should be noted that apartment buildings not exclusively used by students were not included. The maps were then created using the ArcMap 10.4.1. The coordinates for Stellenbosch University student accommodation were collected online using a map of SU's main campus to identify the residences.

In this study, three self-administered questionnaires, focused on three different target groups, namely students residing in HMOs and PBSAs and non-student residents, were used. Convenience sampling was deployed due to the density of the study area. Collectively, 117 HMO students, 131 PBSA students and 71 non-student residents participated in the study. In total there were 319 survey participants. On the whole, the investigation view studentification mainly through the lens of the students and not the owners and managers of the student housing units. These perspectives could be investigated in another study.

\section{Studenfitication: location, motivation, product and impact}

Figure 2 displays the three main types of accommodation used by students at SU. In total, 125 HMOs, 87 PBSA and 26 university residences were identified. A number of student housing clusters can be identified. Cluster one maps the traditional university-provided accommodation that has been in these locations for at least 50 years (some of them for over a century), along with the HMOs and PBSAs in clusters two to six. Each cluster has a unique developmental history (not discussed here). According to Garmendia et al. (2012), the conversion of single-family homes to HMOs represents horizontal studentification, while the occupation of flats instead of HMOs represents vertical studentification. On the whole, clusters two and three are good examples of previous horizontal studentification morphing into vertical studentification. These clusters are located in areas that were white, middleclass, family-focused residential neighbourhoods up to the late 1980s. It should be noted that although there is no historical record ${ }^{2}$ of off-campus student accommodation, a number of properties did have garden cottages that were rented to students, as were flats, mostly to married or postgraduate students. Over time, these properties were first transformed into HMOs, with many of them subsequently demolished and replaced by PBSAs (clusters three and four). The noticeable exception is that of cluster five, which has remained in tack over the past two decades.

\footnotetext{
${ }^{2}$ As a consequence, this analysis is somewhat static as it only really considers the present.
} 


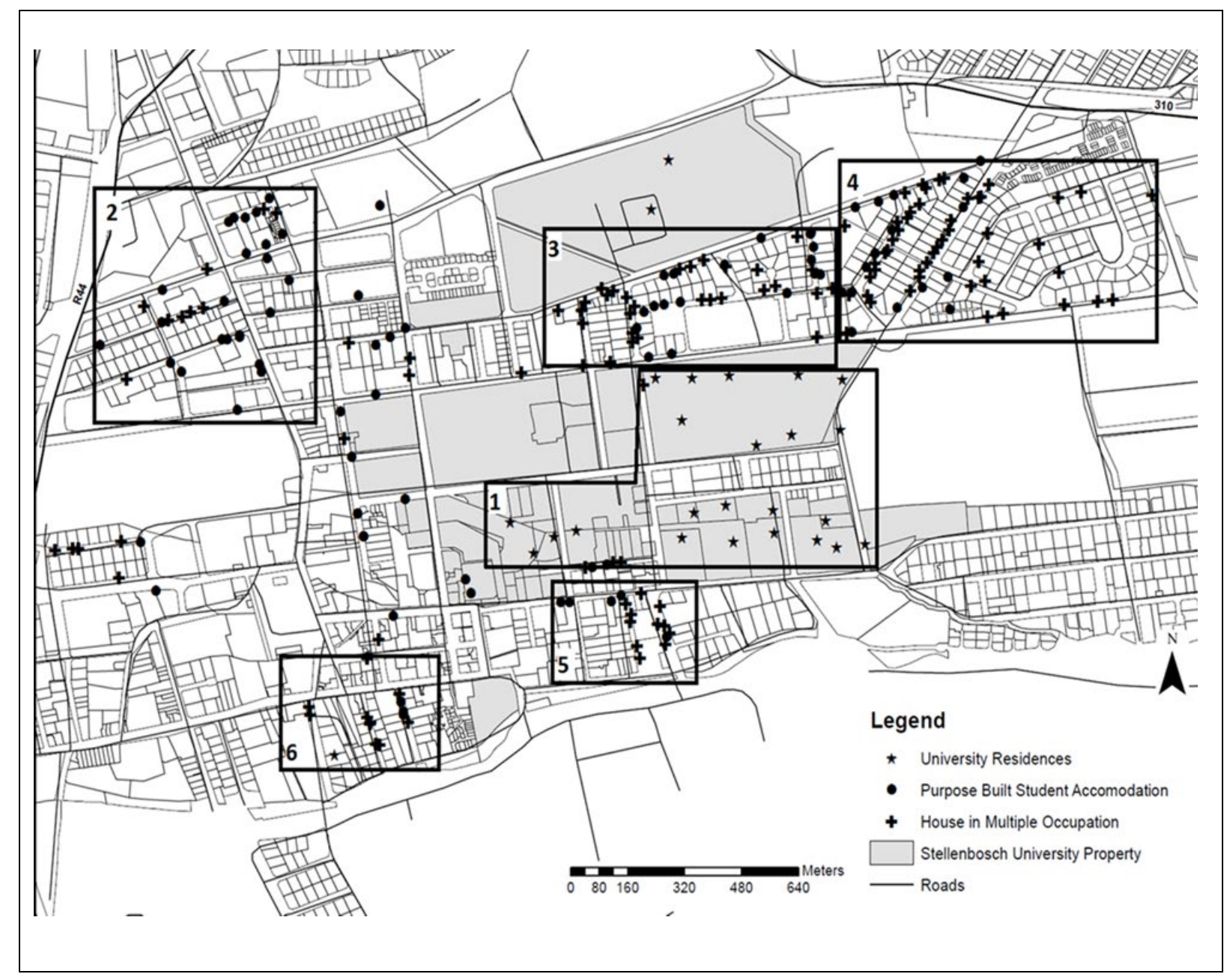

Figure 2: Spatial distribution of the main student accommodation types in Stellenbosch (source: Authors survey).

With the exception of cluster two and six, it is clear that HMOs and PBSAs are mainly clustered adjacent to the campus, yet they are relatively distant from any of Stellenbosch's entertainment zones. In fact, in contrast to the international literature, proximity to the campus stands central and no entertainment nodes of any kind were registered. In addition, no new entertainment nodes have been established owing to studentification. The neighbourhoods where most of the accommodation are found - Universiteits Oord, Die Weides and Simonswyk - are located in clusters three and four and account for more than half of HMOs and PBSAs. According to Benn (2010), this is the result of a number of high density housing complexes that were converted from single-family homes to student housing in these areas. De Weides and Simonswyk are two of the residential areas with the largest student population, which has increased markedly from when Benn's (2010) initial investigation was undertaken. The question then arises as to why students choose to live in these student accommodation clusters.

Figure 3 and 4 indicate the key factors students consider when choosing their accommodation location. The respondents were given a list of six factors that they may or may not consider when choosing a location. For both HMO and PBSA students, safety $(69 \%$ and $73 \%$ respectively) was indicated as a very important consideration. This is followed by distance from campus for PBSA students, and friends who live in the area (58\%) by HMO students. Then again, given the compact nature of Stellenbosch's urban form, this was not really 
surprising. Affordability (59\%) for PBSA students and distance from campus (48\%) for HMO students came in third as a key consideration. What is important is that cost was not the central concern. In a sense, this reflects the fact that the students themselves in many cases do not directly pay, but also that students choosing PBSA accommodation are from middle to high-income backgrounds (see monthly allowance expenditure in Table 4).

Figure 4 indicates the importance of other role-players who influence student's accommodation choice. From the results it is clear that PBSA students found parents $(31 \%)$ and friends $(28 \%)$ to be the most important role-players, whereas HMO students where mostly influenced by friends $(60 \%)$.

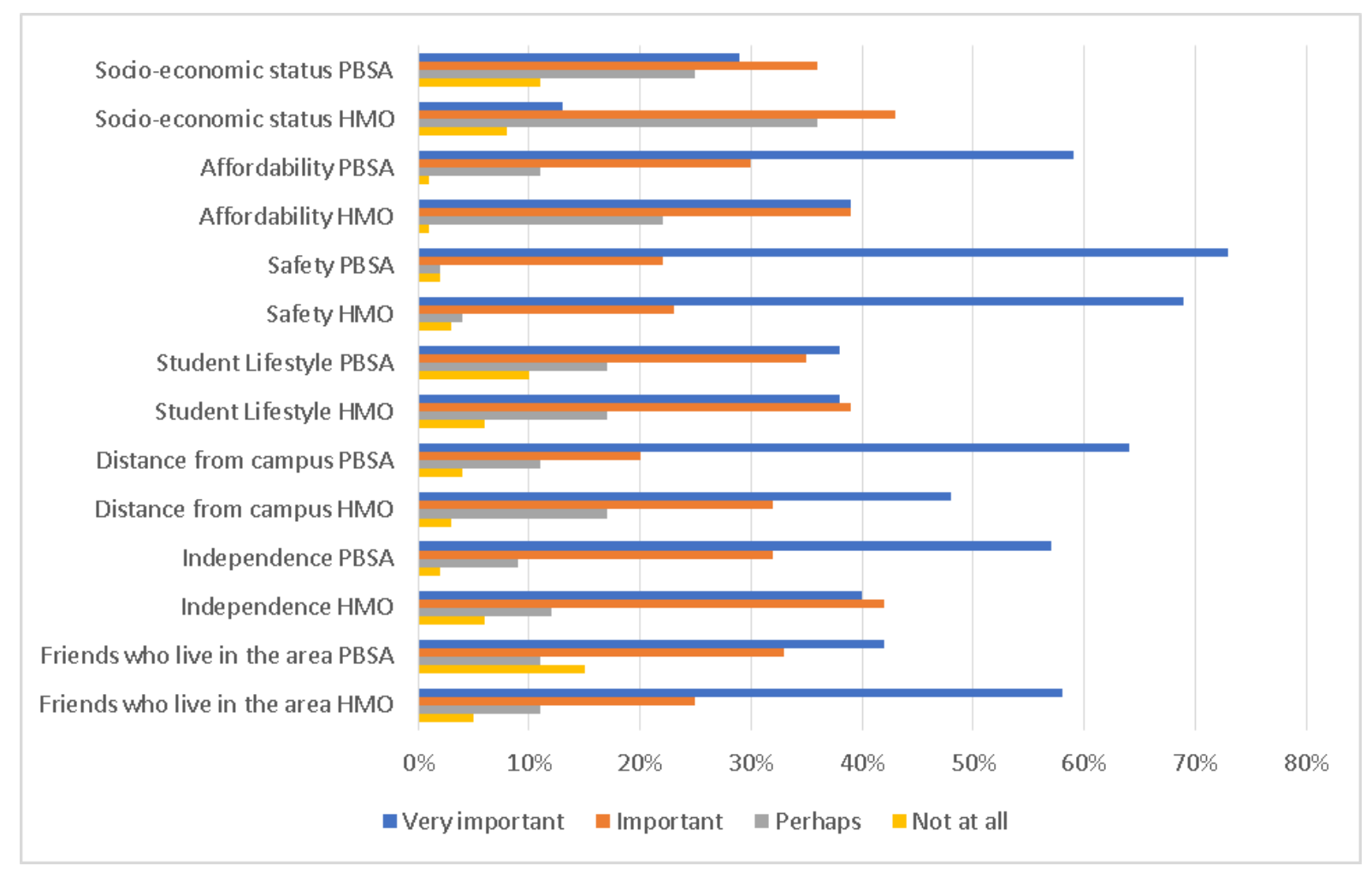

Figure 3: Factors influencing location choice for HMO and PBSA students (source: Authors survey). 


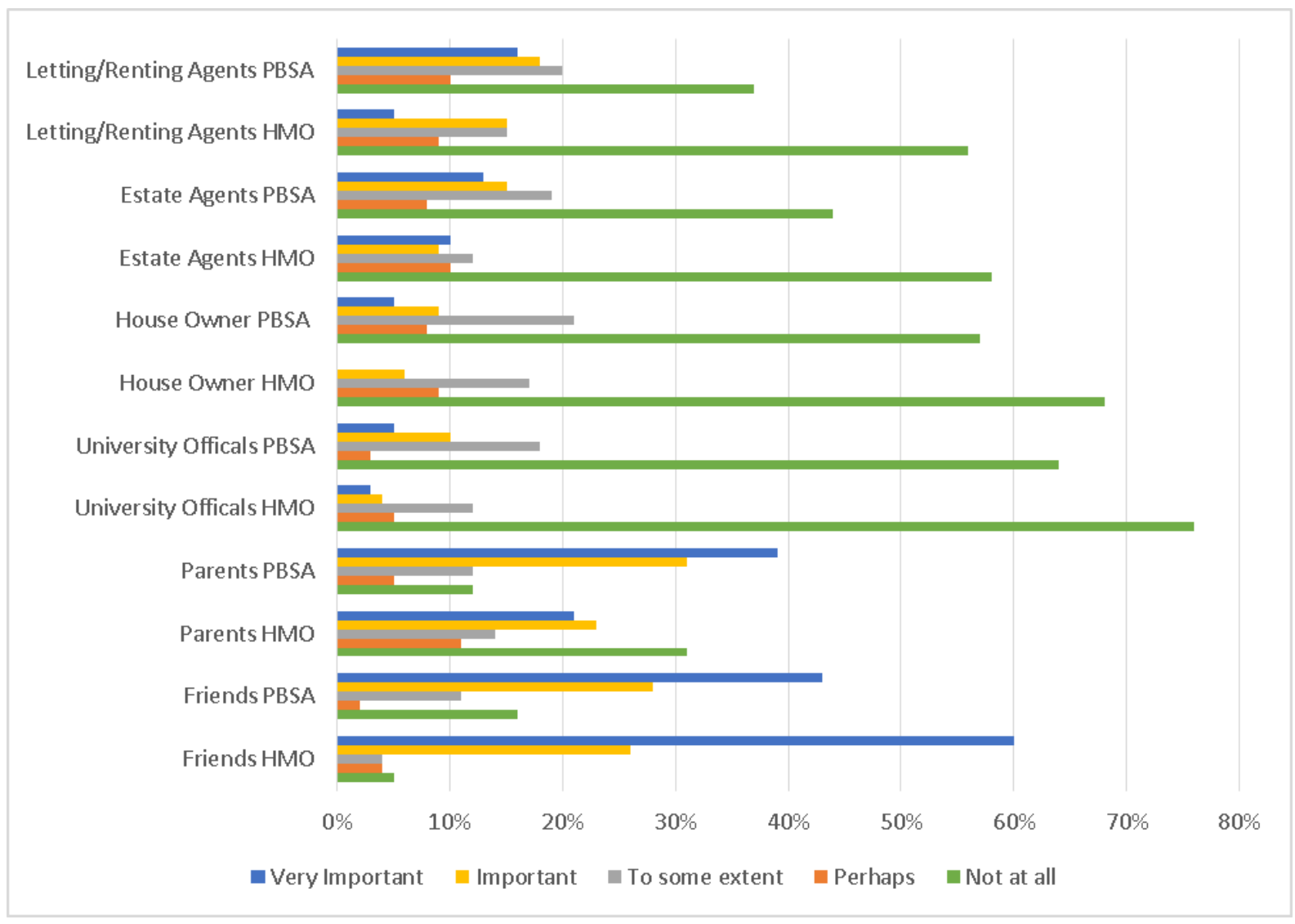

Figure 4: Important role-players influencing access to HMOs and PBSAs (source: Authors survey).

\section{The emergence of HMOs and PBSAs and their characteristics}

The characteristics of HMO and PBSA accommodation in Stellenbosch vary greatly, although it can be argued that the two housing types are becoming increasingly similar in terms of facilities and services. There is also the issue of how individual investors in this property class have migrated from, historically, an individual home owner providing accommodation (having spare space in or on his or her property), to seeing student housing as a property investment class through to large-scale developers, such as CampusKey, becoming involved. Ownership of student accommodation was, however, not part of this investigation, merely its spatial expression and role in urban morphological change.

As argued, there is, however, increasing similarity between HMOs and PBSAs in terms of the facilities and services on offer. The key difference is that of size. This point is supported by the following analysis.

Table 2 profiles the standard facilities and services offered in HMO and PBSA accommodation. In these terms it is recorded that there are no distinct differences between the two student accommodation types. The facilities and services range from basic amenities to "other facilities", which include a gym, laundry room, pool, braai area, security and a garden/patio. Some HMO and PBSA services are paid for separately such as electricity and Internet access. 
Table 2: Facilities and services included in rental accommodation.

\begin{tabular}{lll}
\hline Facilities & HMO & PBSA \\
\hline Kitchen & $100 \%$ & $100 \%$ \\
Bathroom & $100 \%$ & $100 \%$ \\
Lounge/TV room & $97 \%$ & $92 \%$ \\
Parking & $96 \%$ & $95 \%$ \\
Stove & $93 \%$ & $84 \%$ \\
Microwave & $96 \%$ & $88 \%$ \\
Lounge furniture & $93 \%$ & $70 \%$ \\
Bed & $81 \%$ & $82 \%$ \\
Desk & $83 \%$ & $84 \%$ \\
Electricity & $94 \%$ & $84 \%$ \\
Water & $97 \%$ & $99 \%$ \\
Internet (uncapped) & $89 \%$ & $75 \%$ \\
Other & $13 \%$ & $17 \%$ \\
\hline
\end{tabular}

Source: Authors survey.

The costs of HMO and PBSA accommodation, per room, mainly range from R3,000 to R6,000 per month (Table 3). By South African standards the HMOs and PBSAs are expensive for the accommodation provided. The accommodation ranges from a bed in a bachelor flat with en-suite unit to a room with shared communal facilities. To put this in perspective: a three-bedroomed family home can be rented in many cities and towns for R6000.

Table 3: Monthly cost of accommodation.

\begin{tabular}{lll}
\hline Cost of accommodation & HMO & PBSA \\
\hline$<\mathrm{R} 3,000$ & $2 \%$ & $8 \%$ \\
$\mathrm{R} 3,000-\mathrm{R} 6,000$ & $52 \%$ & $71 \%$ \\
$\mathrm{R} 6,000-\mathrm{R}, 8000$ & $46 \%$ & $15 \%$ \\
$>\mathrm{R} 8,000$ & $0 \%$ & $6 \%$ \\
\hline
\end{tabular}

Source: Authors survey.

Table 4 displays the amount of the students' monthly allowance. The majority of the students in both HMO and PBSA receive between R2,000 to R4,000 a month. Although it cannot be established where these funds are spent, it would be reasonable to argue that it ends up in various businesses ranging food to entertainment and clothing within Stellenbosch. Collectively, HMO and PBSA student accommodation in total amounts to around R10,000 a month. The over-arching point, however, is that these students' broader monthly lodging is substantial and require parents or guardians with significant financial means. Table 4 implies that the students participating in the survey are the children of upper-middle and high-income earners.

Table 4: Students' monthly allowance.

\begin{tabular}{lll}
\hline Monthly Allowance & HMO & PBSA \\
\hline$<$ R2000 & $22 \%$ & $36 \%$ \\
R2000-R4000 & $40 \%$ & $36 \%$ \\
R4000-R6000 & $35 \%$ & $24 \%$ \\
$>$ R6000 & $3 \%$ & $4 \%$ \\
\hline
\end{tabular}

Source: Author Survey.

According to Allison (2006), Smith (2009) and Chatterton (2010), the migration of students away from their parents is considered a tradition, as seen, for example in the UK and USA, 
and forms part of the higher education experience. Although there might be HEIs in close proximity to the student's parental home, the idea of leaving home continues to be associated with the idea of leaving for university (Chatterton, 2010). In the context of SU, it has to be stressed that the vast majority of students will have to move to this city, as the city's population itself could never sustain a university based on its permanent residential population. As a consequence, choosing SU in itself implies significant cost. This begs the questions: which socio-economic cohorts can afford to send their child there and where do these students come from?

Figure 5 indicates the different provinces the student respondents living in HMOs and PBSAs originate from. The majority of the students living in both HMOs and PBSA are student migrants from the Western Cape, KwaZulu-Natal, Gauteng and the Eastern Cape. A large number of respondents indicated that they are from the Western Cape, mostly from the City of Cape Town (see Table 5). The overall representation of HMO and PBSA students by province broadly reflects the feeder regions of the university in general. Reasons for differences between the relationship between HMOs and PBSAs by region could not be established.

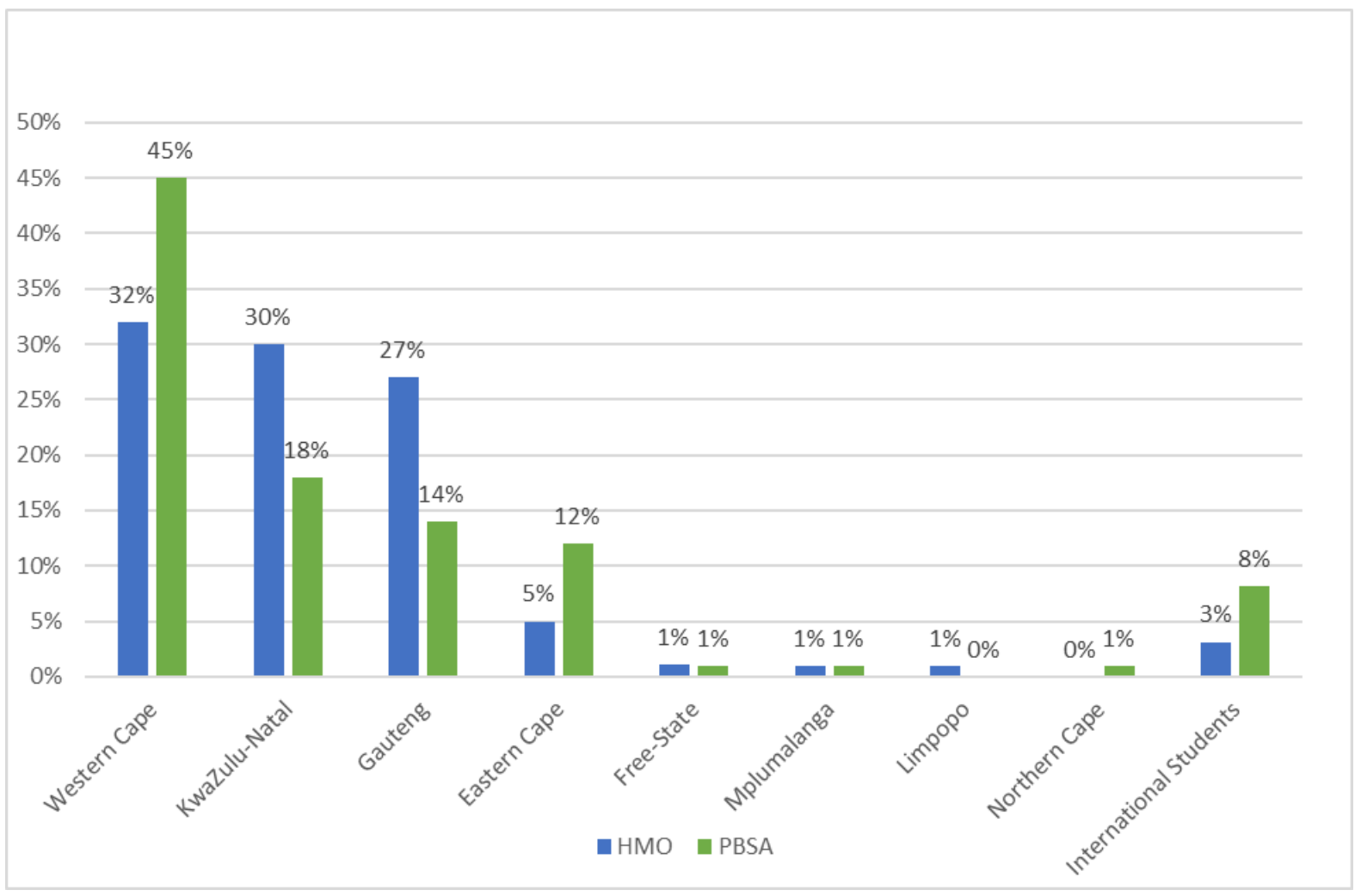

Figure 5: Survey participants by province of origin (source: Authors survey). 
Table 5: Main cities from which students originate.

\begin{tabular}{lll}
\hline Student hometowns & HMO & PBSA \\
\hline Cape Town & $15 \%$ & $20 \%$ \\
Johannesburg & $22 \%$ & $9 \%$ \\
Durban & $19 \%$ & $8 \%$ \\
Pretoria & $1 \%$ & $4 \%$ \\
Other & $43 \%$ & $59 \%$ \\
\hline
\end{tabular}

Source: Authors Survey.

Table 6 provides some insight into a number of demographic characteristics of HMO and PBSA residents. Not surprising, in the SU context the overwhelming majority of the residents are white, and between 18-23 year of age, with more females living in PBSAs, and more males living in HMOs. The higher incidence of women in PBSAs can be ascribed to the fact that this accommodation type typically includes very high levels of on-site security, including security guards. Confirming Benn's (2010) findings, the majority of the students who live in HMOs are in their $3^{\text {rd }}$ year, followed by $2^{\text {nd }}$ year students, whereas students living in PBSAs are spread out across $1^{\text {st }}, 2^{\text {nd }}, 3^{\text {rd }}$ and $4^{\text {th }}$ year.

Table 6: Student Profile.

\begin{tabular}{lll}
\hline & HMO & PBSA \\
\hline Race & & \\
\hline White & $97 \%$ & $78 \%$ \\
Black & $3 \%$ & $8 \%$ \\
Coloured & $0 \%$ & $12 \%$ \\
Indian & $0 \%$ & $1 \%$ \\
Other & $0 \%$ & $1 \%$ \\
\hline Age & & \\
\hline $18-20$ & $51 \%$ & $51 \%$ \\
$21-23$ & $46 \%$ & $44 \%$ \\
$24-26$ & $2 \%$ & $2 \%$ \\
$26>$ & $1 \%$ & $2 \%$ \\
\hline Gender & & \\
\hline Female & $38 \%$ & $53 \%$ \\
Male & $63 \%$ & $47 \%$ \\
\hline Year at SU & & \\
\hline 1st & $5 \%$ & $25 \%$ \\
2nd & $21 \%$ & $21 \%$ \\
3rd & $61 \%$ & $33 \%$ \\
4 th & $7 \%$ & $14 \%$ \\
$>4$ th & $5 \%$ & $7 \%$ \\
\hline Source Aut & &
\end{tabular}

Source: Authors Survey.

On the whole, the vast majority of students are undergraduates. In terms of HMOs, two observations can be made: first, most often, these students started their university careers in 
university-provided accommodation and then moved out after their first or second year of study. This is explained by the notion that HMOs are usually populated by students who have come to know one another in their previous years of study. Second, the male dominance in HMOs was ascribed by respondents to be related to fewer and less stringent house rules. PBSA students tend to have been resident in that type of accommodation from the outset of their studies.

\section{Selected impacts of studentification}

Table 7 provides a list of positive and negative impacts of students' presence, as identified by non-student residents. It is clear that a range of positive and negative impacts were recorded. On the positive side, the increase in property value and improved infrastructure were noted. Interviews with estate agents also suggest that since the development of PBSAs, the attractiveness of those areas have improved, particularly relative to when these areas previously hosted many HMOs. On the negative side, the noise and traffic congestion were highlighted. As suggested in the literature (see Table 1), these impacts can be grouped into four broad categories (Table 8 ).

Table 7: Most frequently mentioned impacts of students.

\begin{tabular}{ll}
\hline Positive & Negative \\
\hline 1. Property value & 1. Noise \\
2. Improved infrastructure & 2. Traffic congestion \\
3. Attractiveness & 3. Decreased availability of parking \\
4. Diversity & 4. Changes in the environment \\
5. Vibrancy & 5. Decreased privacy \\
6. Safer & 6. Lack of family homes \\
7. Business opportunity & 7. Drunkenness \\
8. Social atmosphere & 8. Changes the lifestyle and quality \\
9. Overcrowding & 9. Crime \\
10. Pro-education & 10. Property neglect \\
& 11. Pollution \\
& 12. Decrease in property value \\
& 13. Lack of open areas \\
14. Messy & 15. Students become majority \\
16. Busy shops
\end{tabular}

Source: Authors Survey. 
Table 8: Most frequently mentioned impacts of students (classified).

\begin{tabular}{|c|c|c|c|}
\hline Social & Cultural & Economic & Physical \\
\hline Diversity & Noise & $\begin{array}{ll}\text { Property } & \text { value } \\
\text { increase } & \end{array}$ & Traffic congestion \\
\hline Overcrowding & Drunkenness & $\begin{array}{l}\text { Business } \\
\text { opportunity }\end{array}$ & Decreased availability of parking \\
\hline Social atmosphere & $\begin{array}{l}\text { Changes in lifestyle } \\
\text { and quality }\end{array}$ & $\begin{array}{l}\text { Lack of family } \\
\text { housing }\end{array}$ & Pollution \\
\hline Crime & Vibrancy & Busy shops & Changes in the environment \\
\hline Decreased privacy & & & Property neglect \\
\hline $\begin{array}{l}\text { Students become the } \\
\text { majority }\end{array}$ & & & Lack of open areas \\
\hline Pro-education & & & Attractiveness \\
\hline
\end{tabular}

Source: Authors Survey.

The majority (72\%) of the non-student residents would not want to move out of their current neighbourhood. Relatively few non-student residents who did want to leave preferred neighbourhoods in middle and higher income areas such as Welgevonden, Mostersdrift and Die Boord. Their experience of studentification, however, could not have been extremely negative, because despite two decades of studentification, they still stayed in these neigbourhoods.

Although students and non-student residents can peacefully co-exist, problems arise when non-students residents feel outnumbered (Smith \& Hubbard, 2014). When there are high levels of a minor annoyance, such as noise owing to the presence of a large number of students, it can create animosity between students and non-student residents (Allison, 2006). Other studentification impacts, such as the cultural differences and antisocial behaviour of students, cause unavoidable conflict between these two groups (Benn, 2010). Nearly a third (30\%) of non-student residents stated that they have had disputes with HMO and PBSA students, usually due to noise and more than once. They were also questioned whether they have reported students to the police or the university, and not many $(10 \%)$ have done so. Few of those who reported the students mentioned that they did it more than once; however, one resident claimed he did so more than 20 times. On the other hand, the majority of the students stated that they got along with the non-student residents. It should be noted that a fair number of student respondents stated that there are no non-student residents in their immediate location, which can be related back to the out-migration of non-student residents years ago. On the whole, students and non-students greeted one another daily (92\%) and knew their neighbours well enough to visit or call them (45\%). Confirming Ackermann and Visser (2016) and Benn's (2010) observation, in general, students had no interest in forming relationships with (the few) non-student residents.

\section{Conclusion and some future research avenues}

Studentification in Stellenbosch is certainly not new. Until the 1980s, students were, for the most part, housed in formal SU university residential accommodation. The need for the provision of larger-scale student accommodation became more pronounced during the late 1980s and started to play a key role in residential neighbourhoods in close proximity to the main campus during the 1990s leading into the 2000s. There has been a consolidation of HMOs and PBSAs into clusters in a number of neighbourhoods. The complete transformation of certain parts of Stellenbosch (Die Weides/Universteits Oord - cluster three and four) led to 
homogenous student neighbourhoods. There is also a reconfiguration of HMOs into PBSAs supporting the notion of a first wave of studenfication (HMOs) to a second wave thereof (PBSAs). In terms of South Africa, Stellenbosch provides an extreme example of the impact of studentification on neighbourhoods in which it has taken root and evolved. The impact is perhaps disproportionate in large part as this is a matter of the proportion of student numbers to the permanent non-student population. Current discourse in the popular press does not support the idea of studentification being a national issue yet. As a consequence, this investigation might have limited traction for urban places in South Africa as a whole at this time. Yet, PBSA providers such as CampusKey and Unilofts are now well-established in most large urban places hosting HEIs. It is against this backdrop that one needs to consider this descriptive investigation against a broader backdrop, i.e. why does it matter? Broader urban morphological issues have to be highlighted, some which are perhaps more relevant to the South African context, while others might have greater international resonance.

The first issue relates to the willingness, as opposed to the ability, of HEIs to provide student accommodation. Given other spending pressures, the fact that private investment capital can relieve HEIs of this responsibility needs to be acknowledged and critically examined. For HEIs, in the end, not having to provide student accommodation is simply one less expenditure financially overstretched university-authorities have to consider. Within the South African context, this holds particular pertinence against the backdrop of the national student body who is increasingly insisting on free higher education, which includes accommodation and living expenses. The rise of HMO and PBSA accommodation in particular can serve as a foil against such demands, as HEIs are not involved and the students enter into private contracts with these providers of accommodation. However, affordability issues immediately come to the fore. Irrespective of tuition fees being differentially scrapped for certain income cohorts, the vast majority of South African students simply cannot afford the cost of HMO and PBSA accommodation, if not at SU, then certainly elsewhere. This investigation has been placed in a particular locale - one that is privileged on many fronts that leads to the question of how this study translates to other HEIs in South Africa.

A second set of questions then informs future investigations, not only in Stellenbosch, but in all urban spaces with large or multiple HEIs in South Africa. HMO transformation to PBSAs is evident in Bloemfontein's Universitas and Willows, Cape Town's Observatory and Rondebosch, Johannesburg's Braamfontein and Auckland Park, and Hatfield in Pretoria, where the areas involved are fundamentally being reworked. These locations are all, however, in the metropolitan, large city contexts and concerns historically "white" institutions. The question immediately arises as to the relevance of this investigation to rural or smaller urban contexts and the impacts of HEIs' accommodation shortfalls on the surrounding communities generally, but also on the spatial occurrence and form, in particular. What is the impact of studentification in places like Alice (University of Fort Hare), Umtata (Walter Sisulu University) or Polokwane (University of Limpopo), to name a few locations?

Drawing on the Stellenbosch experience, there is the issue of market saturation being reached. All South African universities have now capped the number of students it can accommodate. This situation in national higher education funding constraints is highly unlikely to change in the next decade or so. Given that HMO properties are often cheaply converted to student use, those properties lose their desirability to prospective home buyers who generally will have to invest heavily if converting the property to more traditional residential accommodation. This investigation joins Donaldson et al. (2014) who noted that there are challenges regarding the regulation of student housing. In Stellenbosch, 
studentification has, in large part, taken place without much planning or intervention from the local authority planning department, nor is there seemingly any policing of how building regulations are being ignored. The impact of purpose-built student accommodation, as opposed to general family homes being reworked as student accommodation, requires careful consideration. At the broader level, similar investigations should be undertaken into how this process might have (or might not have) resonance in other developing countries, not least in African urban places.

In terms of linking this investigation to a broader studentification discourse, a few further observations can be made.

The development of HMOs had a negative effect on the physical form of neighbourhoods in which they initially developed. However, the transitioning of HMOs to PBSAs has improved the physical appearance of the affected areas. Unlike indicated in the international literature, none of the Stellenbosch studentified clusters have led to the establishment of entertainment nodes, nor student focused retailers of service providers in the relevant areas. A key comparative research question could be how and why this is the case. In addition, there has been very little general public outcry concerning either these students' presence or the process of studentification. This process has not so far seen local government regulatory responses at all beyond keeping residential areas "residential" and not allowing other land uses in the relevant areas. Socio-culturally, the "historic/past" permanent middle/uppermiddle class was replaced by students coming from similar backgrounds. What has changed is the age profile of the affected areas and the housing profile - single-family residences became horizontally studentified HMOs, which are now becoming larger and higher structures through vertical studentification. The process of studentification has not been explored in the HEIs base in rural areas and the potential for studentification in smaller towns with HEIs require attention, particularly as they are poorly resourced and cater to overwhelmingly financially marginalised student populations. It also needs to be kept in mind that HEIs' modes of education delivery is in flux and the role of the traditional residential university is very likely to change. Perhaps larger numbers of students might be a continuing trend going forwards, but whether it will do so in the current mode of delivery is highly unlikely. This will challenge the constant addition of student housing and its longer-term sustainability. The plus side might be that student housing that have not been converted in the central parts of Stellenbosch might be increasingly released either as rental or owned housing stock for non-students. This in turn can also aid in tempering constant rental and property value increase. Finally, an investigation into who invests in student accommodation, and why, is needed. Taken together, the process of studentification in South African urban change is in its infancy and requires extensive scholarly attention.

Gustav Visser, Stellenbosch University, Department of Geography and Environmental Studies, Matieland South Africa (gevisser@sun.ac.za)

Dene Kisting, Stellenbosch University, Department of Geography and Environmental Studies, Matieland, South Africa (18385397@sun.ac.za)

\section{Acknowledgements}

We extend our thanks and appreciation to the survey participants for their time and insights. We are also grateful for the comments made by James Gregory and Gijsbert Hoogendoorn on an earlier version of this paper. The 
usual disclaimers apply. Funding support by the National Research Foundation, Pretoria, is also gratefully acknowledged.

\section{References}

Ackermann, A. \& Visser, G. (2016) Studentification in Bloemfontein, South Africa. Bulletin of Geography. Socio-economic Series, 31(1), pp. 7-17.

Allison, J. (2006) Over-educated, over-exuberant, and over here? The impact of students on cities. Planning, Practice and Research, 21(1), pp. 79-94. DOI: 10.1080/02697450600901541

Benn, J. (2010) Studentifikasie in Stellenbosch. Master's thesis. Stellenbosch, Stellenbosch University, Department of Geography and Environmental Studies.

Boersma, K., Lagen, H. \& Smets, P. (2013) Paradoxes of studentification: social mix versus gentrification in a disadvantaged neighbourhood in Amsterdam. The Open Urban Studies Journal, 6 (Supplement 1 M3), pp. 40-49. DOI: $10.2174 / 1874942901306010040$

Chatterton, P. (1999) University students and city centers - the formation of exclusive geographies: the case of Bristol, UK. Geoforum, 30(1), pp. 117-133. DOI: 10.1016/S0016-7185(98)00028-1

Chatterton, P. (2010) The student city: an ongoing story of neoliberalism, gentrification, and commodification. Environment and Planning, 42(1), pp. 509-514. DOI: 10.1068/a42293

Cochrane, A. \& Williams, R. (2013) Putting higher education in its place: the socio-economic geography of English universities. Policy and Politics, 41(1), pp. 43-58. DOI: 10.1332/030557312X645775

Council for Higher Education (2016) South African higher education reviewed: Two decades of democracy. Pretoria.

Donaldson, R. (2014) The production of quartered spaces in Stellenbosch (inaugural address: 4 September 2014).

Donaldson, R., Benn, J., Campbell, M. \& de Jager, A. (2014) Reshaping urban space through studentification in two South African urban centres. Urban Izziv, 25(1), pp. 177-186.

Garmendia, M., Coronado, J. M. \& Urena, J. M. (2012) University students sharing flats: when studentification becomes vertical. Urban Studies, 49(12), pp. 2651-2668. DOI: 10.1177/0042098011428176

Fincher, R. \& Shaw, K. (2011) Enacting separate social worlds: "international" and "local" students in public space in central Melborne. Geoforum, 42(5), pp. 539-549. DOI: 10.1016/j.geoforum.2011.05.002

Hubbard, P. (2008) Regulating the social impacts of studentification: a Loughborough case study. Environment and Planning, 40(1), pp. 323-341. DOI: 10.1068/a396

Hubbard. P. (2009) Geographies of studentification and purpose-built student accommodation: leading separate lives? Environment and Planning, 41(1), pp. 1903-1923. DOI: 10.1068/a4149

Macintyre, C. (2003) New models of student housing and their impact on local communities. Journal of Higher Education, 25(2), pp. 109-118. DOI: 10.1080/1360080032000122598

Munro, M., Turok, I. \& Livingston, M. (2009) Students in cities: a preliminary analysis of their patterns and effects. Environment and Planning, 41(1), pp. 1805-1825. DOI: 10.1068/a41133

Ordor, U., Cattell, K., Michell, K. \& Bowen, P. (2010) The effects of studentification on the residential neighbourhood of a university suburb: a study of the University of Cape Town in Rondebosch. In: Da Graca, M.A.E. (ed.) Proceedings of CIB W070 International Conference in Facilities ManagementFMin the Experience Economy, pp. 13-15. Sao Paulo, University of Sao Paulo Press.

Rugg, J., Rhodes, D. \& Jones, A. (2002) Studying a niche market: UK students and the private rented sector. Housing Studies, 19(2), pp. 289-303. DOI: 10.1080/02673030220123234

Sage, J., Smith, D. \& Hubbard, P. (2012a) The diverse geographies of studentification: living alongside people not like us. Housing Studies, 27(8), pp. 1057-1078. DOI: 10.1080/02673037.2012.728570

Sage, J., Smith, D. \& Hubbard, P. (2012b) The rapidity of studentification and population change: there goes the studenthood. Population, Space, and Place, 18, pp. 597-613. DOI: 10.1002/psp.690

Smith, D. (2005) 'Studentification': the gentrification factory? In: Atkinson, R. \& Bridge, G. (eds.) Gentrification in a global context: the new urban colonialism, pp. 73-90. London and New York: Routledge Taylor and Francis Group. DOI: 10.4324/9780203392089_chapter_5

Smith, D. \& Holt, L. (2007) Studentification and 'apprentice' gentrifiers within Britain's provincial towns and cities: extending the meaning of gentrification. Environment and Planning, 39(1), pp. 142-161. DOI: $10.1068 / \mathrm{a} 38476$

Smith, D. (2009) 'Student geographies', urban restructuring, and the expansion of higher education. Environmental and Planning A, 41(8), pp. 1795-1804. DOI: 10.1068/a42257

Smith, D. \& Hubbard, P. (2014) The segregation of educated youth and dynamic geographies of studentification. Area, 41(1), pp. 92-100. DOI: 10.1111/area.12054 
Stellenbosch University (2017a): Available at: https://www.sun.ac.za/english/statistical-profile-2014-test (accessed 30 Sept. 2017).

Stellenbosch (2017b): Available at: https://www.sun.ac.za/english/maties/Documents/Placement\%20Policy.pdf (accessed 30 Sept. 2017).

Steinacker, A. (2005) The economic effect on urban colleges on their surrounding communities. Urban Studies, 42(7), pp. 1161-1175. DOI: 10.1080/00420980500121335 